\title{
Sports Dentistry and Sports Medicine: an Analysis by Brazilian Regions
}

\section{Odontologia do Esporte e Medicina Esportiva: uma Análise por Regiões Brasileiras}

\author{
Thamyres Maria Silva Simões ${ }^{\text {a; }}$ Maria Helena Chaves de Vasconcelos*a \\ ${ }^{\text {aS }}$ tate University of Paraíba, Post-Graduate Program in Dentistry. PB, Brazil. \\ *E-mail: mhcvcatao@gmail.com \\ Recebido em: 02/07/2020 \\ Aprovado em: 27/11/2020
}

\begin{abstract}
The aim of this study was to quantitatively assess the number of dentists who are specialists in Sports Dentistry and Specialist Physicians who are specialists in Sports Medicine, according to the Brazilian regions. The total number of dentists and doctors in Brazil and specialists in Sports Dentistry and Sports Medicine was collected on the websites of the Federal Council of Dentistry (CFO) and the Federal Council of Medicine (CFM), respectively. All data used in this research are publicly accessible. Rio de Janeiro and Minas Gerais are the Brazilian states with the largest number of specialist dentists in Sports Dentistry $(\mathrm{n}=5)$ and São Paulo, the state with the highest number of sports medicine specialists $(\mathrm{n}=236)$. By Brazilian regions, it was observed that most professionals specialized in Sports Dentistry $(55.6 \%)$ and Sports Medicine $(49.5 \%)$ are located in the Southeast region. In the Northeast region, for each specialist in Sports Dentistry, there are 109 physicians specialized in this therapy (1/109). There is a small number of dentists who are specialists in Sports Dentistry, when compared to the number of physicians specialized in Sports Medicine, mainly in the North and Northeast regions of the country.
\end{abstract}

Keywords: Dentistry. Sports. Sports Medicine. Oral Health.

\section{Resumo}

O objetivo deste estudo foi avaliar quantitativamente o número de cirurgiões-dentistas especialistas em Odontologia do Esporte e médicos especialistas em Medicina Esportiva, de acordo com as regiões brasileiras. O número total de cirurgiões-dentistas e médicos no Brasil e de especialistas em Odontologia do Esporte e Medicina Esportiva, foi coletado nos sites do Conselho Federal de Odontologia (CFO) e Conselho Federal de Medicina (CFM), respectivamente. Todos os dados utilizados nesta pesquisa são de acesso público. O Rio de Janeiro e Minas Gerais são os estados brasileiros com o maior número de cirurgiões-dentistas especialistas em Odontologia do Esporte (n=5) e São Paulo, o estado com o maior número de médicos especialistas em Medicina Esportiva $(n=236)$. Por regiões brasileiras, observou-se que a maioria dos profissionais especialistas em Odontologia do Esporte (55,6\%) e em Medicina Esportiva (49,5\%) estão localizados na região Sudeste. Na região Nordeste, para cada especialista em Odontologia do Esporte, existem 109 médicos com especialização nesta terapia (1/109). Há uma pequena quantidade de cirurgiões-dentistas especialistas em Odontologia do Esporte, quando comparados ao número de médicos especialistas em Medicina Esportiva, principalmente nas regiões Norte e Nordeste do país.

Palavras-chave: Odontologia. Esportes. Medicina Esportiva. Saúde Bucal.

\section{Introduction}

Sports Medicine is a medical specialty that presents strong multidisciplinary evidence, involving care in all age groups, both in the general population and in high-income athletes Likewise, all other health areas that act connected to the medical department of a sports entity, such as dentistry, have this objective, that is, they seek to prioritize the athlete's or sports team performance ${ }^{2}$.

Oral health is an integral and inseparable part of the individual's general health ${ }^{3,4}$, being directly related to risks of systemic bacterial dissemination with consequent decrease in physical performance, especially in athletes. Thus, an important segment of Dentistry associated with sport has been established over the years in the country ${ }^{5,6}$.

In Brazil, the first representative of this area was Mário Hermes Trigo de Loureiro, a dental-surgeon of the Brazilian Team in the World cups from 1958 to 1970 . According to him, oral health could be responsible for weakening the general health and performance of sportsmen during competitions, observing a rapid recovery after the elimination of the dental infection foci. In 1958,118 teeth were removed from the 33 athletes in the team ${ }^{7,8}$.

In 2015, through Resolution 160/2015, the Federal Dentistry Council (CFO) recognized the Sport Dentistry as a specialty ${ }^{7}$. Since then, this specialty has grown and solidified every day, but few clubs have exclusive dental departments and are integrated into health departments ${ }^{5}$.

Sports Dentistry addresses the prevention and treatment of athletes' orofacial injuries and related diseases, as well as the dissemination of the type and frequency of these injuries, in addition to the carrying out of research aimed at their prevention. In addition, it is committed to communicate to sportsmen, as well as to the entire population, the importance of oral health and the acquisition of healthy habits for the 
maintenance of integral health ${ }^{5,9}$.

Dental caries, dental erosion and periodontal problems are common in the sports community, and many traumas could be avoided by using a protective device correctly ${ }^{8}$. According to the National Youth Sports Foundation (NYSF), contact sports athletes have about $10 \%$ more chance of suffering orofacial injuries during a sports competition, and this activity is responsible for about one third of all dental injuries ${ }^{9}$.

The dental surgeon performance in the sports context is not only the indication and manufacture of oral protectors but also as a preventive measure for dental traumas ${ }^{5}$. His or her field of work is much wider, contemplating the study of direct or indirect oral manifestations that may affect the sportsman's performance. Therefore, dental follow-up should be part of the athlete's routine, thus preventing the appearance of certain pathologies through clinical and radiographic examinations ${ }^{10}$.

Knowing the importance of integral health in sports practice and the need for skilled professionals, the objective of this study was to quantitatively evaluate the number of dentists specialized in Sports Dentistry and physicians specialized in Sports Medicine, according to Brazilian regions.

\section{Material and Methods}

It is a cross-sectional descriptive study, with quantitative approach. The data regarding the number of specialists in Sports Dentistry and Sports Medicine were researched at the websites of the Federal Dentistry Council (CFO) and the Federal Medical Council (CFM), respectively, as well as the geographic distribution of the number of specialists according to the Brazilian states. The research was carried out between December 2019 and January 2020, thus obtaining the exact number of specialist professionals, duly recognized in the CFO and CFM, until the date of search. All data used in this research are publicly accessible.

\section{Results and Discussion}

The Southeast region has the highest number of specialists in Sports Dentistry $(n=10)$ and Sports Medicine $(n=366)$, with Rio de Janeiro and Minas Gerais the Brazilian states with the highest number of dental-surgeon specialized in Sports Dentistry $(n=5)$ (Table 1) and São Paulo, the state with the highest number of physicians specialized in Sports Medicine $(\mathrm{n}=236)$ (Chart 2)

Table 1 - Distribution of the total number of dental surgeons, specialized in Sports Dentistry and the specialist/dental-surgeon ratio per Brazilian state.

\begin{tabular}{|c|c|c|c|}
\hline State & $\begin{array}{c}* \text { Specialists } \\
\text { in Sports } \\
\text { Dentistry } \\
\text { (n) }\end{array}$ & $\begin{array}{c}* * \text { Dental- } \\
\text { Surgeons } \\
\text { (n) }\end{array}$ & $\begin{array}{c}\text { Specialist/ } \\
\text { Dental- } \\
\text { Surgeon- } \\
\text { Dentist ratio }\end{array}$ \\
\hline Acre & 0 & 1444 & $0 / 1444$ \\
\hline Alagoas & 0 & 4419 & $0 / 4419$ \\
\hline Amapá & 0 & 1460 & $0 / 1460$ \\
\hline Amazonas & 0 & 7319 & $0 / 7319$ \\
\hline
\end{tabular}

\begin{tabular}{|c|c|c|c|}
\hline Bahia & 0 & 19379 & $0 / 19379$ \\
\hline Ceará & 1 & 11068 & $1 / 11068$ \\
\hline Distrito Federal & 0 & 12977 & $0 / 12977$ \\
\hline Espírito Santo & 0 & 8781 & $0 / 8781$ \\
\hline Goiás & 1 & 17158 & $1 / 17158$ \\
\hline Maranhão & 0 & 6760 & $0 / 6760$ \\
\hline Mato Grosso & 1 & 8597 & $1 / 8597$ \\
\hline Mato Grosso do Sul & 0 & 6974 & $0 / 6974$ \\
\hline Minas Gerais & 5 & 55031 & $1 / 11006.2$ \\
\hline Pará & 0 & 9025 & $0 / 9025$ \\
\hline Paraíba & 0 & 7477 & $0 / 7477$ \\
\hline Paraná & 1 & 30272 & $1 / 30272$ \\
\hline Pernambuco & 0 & 13968 & $0 / 13968$ \\
\hline Piauí & 0 & 4639 & $0 / 4639$ \\
\hline Rio de Janeiro & 5 & 48460 & $1 / 9692$ \\
\hline $\begin{array}{l}\text { Rio Grande do } \\
\text { Norte }\end{array}$ & 0 & 5996 & 0/5996 \\
\hline Rio Grande do Sul & 2 & 27436 & $1 / 13718$ \\
\hline Rondônia & 0 & 3783 & $0 / 3783$ \\
\hline Roraima & 0 & 1272 & $0 / 1272$ \\
\hline Santa Catarina & 2 & 18147 & $1 / 9073.5$ \\
\hline São Paulo*** & 0 & 87348 & $0 / 87348$ \\
\hline Sergipe & 0 & 3217 & $0 / 3217$ \\
\hline Tocantins & 0 & 3531 & $0 / 3531$ \\
\hline TOTAL & 18 & 425,398 & $1 / 320,573.7$ \\
\hline
\end{tabular}

* Total of specialists in Sports Dentistry inscribed in Brazil according to CFO.

* Overall total of dental-surgeons in Sports Dentistry inscribed in Brazil according to CFO.

*** The state of São Paulo has no information, until the date of the search, about the number of specialists in Sports Dentistry.

Source: Research data.

Table 2 - Distribution of the total number of physicians, specialists in Sports Medicine and the specialist/doctor ratio by Brazilian state.

\begin{tabular}{|c|c|c|c|}
\hline State & $\begin{array}{c}\text { *Specialists } \\
\text { in Sports } \\
\text { Medicine } \\
\text { (n) }\end{array}$ & $\begin{array}{c}\text { **Physicians } \\
\text { (n) }\end{array}$ & $\begin{array}{c}\text { Specialist/ } \\
\text { Physician } \\
\text { ratio }\end{array}$ \\
\hline Acre & 1 & 1018 & $1 / 1018$ \\
\hline Alagoas & 23 & 5200 & $1 / 226.1$ \\
\hline Amapá & 8 & 5308 & $1 / 663.5$ \\
\hline Amazonas & 0 & 955 & $0 / 955$ \\
\hline Bahia & 36 & 24269 & $1 / 674.1$ \\
\hline Ceará & 15 & 14869 & $1 / 991.3$ \\
\hline Distrito Federal & 33 & 15546 & $1 / 471.1$ \\
\hline Espírito Santo & 13 & 10873 & $1 / 836.4$ \\
\hline Goiás & 19 & 15709 & $1 / 826.8$ \\
\hline Maranhão & 8 & 7502 & $1 / 937.8$ \\
\hline Mato Grosso & 4 & 6458 & $1 / 1614.5$ \\
\hline Mato Grosso do Sul & 12 & 6364 & $1 / 530.3$ \\
\hline Minas Gerais & 47 & 55888 & $1 / 1189.1$ \\
\hline Pará & 13 & 9139 & $1 / 703$ \\
\hline Paraíba & 3 & 8004 & $1 / 2668$ \\
\hline Paraná & 48 & 28034 & $1 / 584$ \\
\hline Pernambuco & 12 & 19233 & $1 / 1602.8$ \\
\hline Piaú & 3 & 5132 & $1 / 1710.7$ \\
\hline Rio de Janeiro & 70 & 65812 & $1 / 940.2$ \\
\hline Rio Grande do & 3 & 6646 & $1 / 2215.3$ \\
\hline Norte & 72 & 32859 & $1 / 456.4$ \\
\hline Rio Grande do Sul & & & \\
\hline
\end{tabular}




\begin{tabular}{|c|c|c|c|}
\hline Rondônia & 0 & 2989 & $0 / 2989$ \\
\hline Roraima & 1 & 921 & $1 / 921$ \\
\hline Santa Catarina & 52 & 18687 & $1 / 359.4$ \\
\hline São Paulo & 236 & 145953 & $1 / 618.4$ \\
\hline Sergipe & 6 & 4365 & $1 / 727.5$ \\
\hline Tocantins & 1 & 3007 & $1 / 3007$ \\
\hline Total & $\mathbf{7 3 9}$ & $\mathbf{5 2 0 , 7 4 0}$ & $\mathbf{1 / 3 9 , 7 9 3 . 1}$ \\
\hline
\end{tabular}

* Total of specialists in Sports Medicine inscribed in Brazil according to CFN.

* Overall total of physicians inscribed in Brazil according to CFM.

Source: Research data.
Although recognized as a specialty by the CFO through Resolution 160/2015 , nineteen states, including all states of the Northern region of the country, do not still have dentists specialized in Sports Dentistry or do not present information about these professionals.

Ceará is the only state in the Northeast region with a specialist in Sports Dentistry ( $\mathrm{n}=1)$, where for each specialist dental surgeon, there are 109 physicians specialized in this therapy $(1 / 109)$ (Table 3$)$.

Table 3 - Percentage distribution of professionals, specialists in Sports Dentistry and Sports Medicine, and the ratio between dental surgeon specialist/specialist physician by Brazilian region.

\begin{tabular}{|c|c|c|c|c|c|}
\hline Region & $\begin{array}{c}\text { Specialists in } \\
\text { Sports Dentistry } \\
\mathbf{n}(\mathbf{( \% )}\end{array}$ & $\begin{array}{c}\text { Dental Surgeons } \\
\mathbf{n}(\mathbf{\%})\end{array}$ & $\begin{array}{c}\text { Specialists in } \\
\text { Sports Medicine } \\
\mathbf{n}(\mathbf{\%})\end{array}$ & $\begin{array}{c}\text { Physicians } \\
\mathbf{n}(\%)\end{array}$ & $\begin{array}{c}\text { *Dental-Surgeon/ } \\
\text { Physician ratio }\end{array}$ \\
\hline North & $0(0 \%)$ & $27834(6.5 \%)$ & $24(3.2 \%)$ & $23337(4.5 \%)$ & $0 / 24$ \\
\hline Northeast & $1(5.6 \%)$ & $76923(18.1 \%)$ & $109(14.7 \%)$ & $95220(18.2 \%)$ & $1 / 109$ \\
\hline Mid-West & $2(11.1 \%)$ & $45706(10.7 \%)$ & $68(9.2 \%)$ & $44077(8.5 \%)$ & $1 / 34$ \\
\hline Southeast & $10(55.6 \%)$ & $199620(46.9 \%)$ & $366(49.5 \%)$ & $278526(53.5 \%)$ & $1 / 36.6$ \\
\hline South & $5(27.8 \%)$ & $75855(17.8 \%)$ & $172(23.2 \%)$ & $79580(15.3 \%)$ & $1 / 34.4$ \\
\hline Total & $\mathbf{1 8 ( 1 0 0 \% )}$ & $\mathbf{4 2 5 , 3 9 8}(\mathbf{1 0 0} \%)$ & $\mathbf{7 3 9}(\mathbf{1 0 0} \%)$ & $\mathbf{5 2 0 , 7 4 0}(\mathbf{1 0 0} \%)$ & $\mathbf{1 / 2 3 8}$ \\
\hline
\end{tabular}

* Ratio between the number of dentists specialized in Sports Dentistry registered in CRO and physicians specialized in Sports Medicine registered in CFM. Source: Research data.

Integral care with the sportsman's health has been widely studied, since the athlete needs to be physically and psychologically healthy to obtain good results. However, Dentistry is not still properly valued as a science that contributes significantly to the athlete's sporting performance and few professionals study and communicate this interrelation ${ }^{11}$, as observed in the results presented in this research (Table 3). There are 18 specialists in Sports Dentistry, while Sports Medicine has 739 specialist physicians.

Noteworthy attention should be given to the number of professionals specialized in Sports Dentistry and Sports Medicine in the Southeast and South regions in contrast to the other regions of the country, which can be justified by these two regions concentrating the largest clubs, confederations and sports associations in Brazil.

Costa $^{10}$, in evaluating the correct indication and use of oral protectors, especially in athletes who practice confrontation or speed sports, highlighted the importance of the dental surgeon insertion in multidisciplinary sports health teams. Dental care should be part of the initial and periodic health care protocol for sports practice, increasing the Piaui athlete's physical performance, taking into account the metabolic differences, the training phase the same is in, dental problems, medications and also substances considered doping, and not just the traumas prevention ${ }^{12,13}$

When evaluating interdisciplinarity within clubs, Silva et al. ${ }^{14}$ concluded that among the health professionals, the dental surgeon was the least hired, which demonstrates a lack of knowledge on the pathogenic potential of many bacterial forms, natural inhabitants of the oral cavity, and their possible manifestations in other systems of the organism².
Sports Medicine is also presented as a medical specialty with a great shortage of professionals in clubs, associations and sports associations, and even in schools and in the Family Health Program, where adequate stimulation and orientation of physical activity should be a mandatory part of health promotion programs, as observed in the study by Hernandez ${ }^{1}$.

It should be borne in mind that when an area or specialty does not have its benefits and its importance well recognized by the market, demand for this specialization tends to decrease. In addition, there is the possibility that some professionals may already be specialists, but have not registered yet with $\mathrm{CFO}$ or CFM.

Sports practice, because it has become increasingly a habit of life, needs the greater intervention of Sports Dentistry, since it has a predominant role in the prevention and treatment of oral diseases or traumas, in order to increase the athletes' performance in competitions $\mathbf{s}^{10,15,16}$.

\section{Conclusion}

Despite the benefits brought by the insertion of Sports Dentistry and Sports Medicine in the sports health team, a small number of specialized dental-surgeons are also observed throughout Brazil, mainly in the Northeast and North regions, when compared to the number of specialists. Thus, it is necessary that these professionals know the importance of oral health in the athlete's sporting performance, as well as communicate this interrelation to the sportsmen and the population.

\section{References}

1. Hernandez AJ. Perspectivas profissionais da Medicina 
do Esporte. Rev Med 2012;91(1):9-13. doi: https://doi. org/10.11606/issn.1679-9836.v91i1p9-13.

2. Pastore GU, Moreira M, Bastos R, Galotti M, Leonardi MFP. Odontologia do esporte: uma proposta inovadora. Rev Bras Med Esporte 2017; 23(2).

3. Janket S, Qvartnströn M, Meurman JH, Baird AE, Nuutinen P, Jones JA. Asymptotic dental score and prevalent coronary heart disease. Circulation 2004;109:1095-100. doi: https:// doi.org/10.1161/01.CIR.0000118497.44961.1E.

4. Matilla KJ, Pussinen PJ, Paiu S. Dental infections and cardiovascular diseases: a review. J Periodontol 2005;76(11):1085-8. doi: https://doi.org/10.1902/ jop.2005.76.11-S.2085.

5. Alves DCB, Anjos VDL, Giovannini JFBG, Lima RPE, Souza SM. Odontologia no esporte: conhecimento e hábitos de atletas do futebol e basquetebol sobre saúde bucal, Rev Bras Med Esporte 2017; 23(5).

6. Assis C. Os rumos da odontologia do esporte no Brasil. Rev Bras Odontol 2013;70(2):160-4.

7. Conselho Federal de Odontologia. Odontologia do Esporte agora é especialidade. [acesso en 5 jan 2920]. Disponível em http://cfo.org.br/website/odontologia-do-esporte-agora-eespecialidade/.

8. Costa SS, Maia DAC, Costa IZ, Chauvin Netto JF, Feitosa EA, Venâncio AEF, Fidelis RT. Odontologia desportiva: melhor performance com a atuação do dentista na prática da atividade física. Col Pesq Educ Fís 2015;14(4):131-13.
9. Dhillon BS, Sood N, Sah N, Arora D, Mahendra A. Guarding the precious smile: incidence and prevention of injury in sports: a review. J I Oral Health. 2014:104-107.

10. Costa SS. Odontologia desportiva na luta pelo reconhecimento. Rev Odontol Univ 2009;21(2):162-8.

11. Smith WS, Kracher CM. Sports-Related Dental Injuries and Sports Dentistry. Dent Assist 1998;67(3):12-6.

12. Andrade LGN, Silva MA, Giffoni JJ, Castro Filho CS. Os desafios da odontologia no esporte: uma nova perspectiva: revisão de literatura. Revista Diálogos Acadêmicos. 2017; 6 (2).

13. Bastos RS, Vieira EMM, Simões CAD, Peres SHC, Caldana ML, Lauris JRP. Odontologia desportiva: proposta de um protocolo de atenção à saúde bucal do atleta. Rev Gaúcha Odontol. 2013; 61:461-8.

14. Silva AA, Bittencourt NFN, Mendonça LM, Tirado MG, Sampaio RF, Fonseca ST. Análise do perfil, funções e habilidades do fisioterapeuta com atuação na área esportiva nas modalidades de futebol e voleibol no Brasil. Rev Bras Fisioter. 2011;15(3):219-26.

15. Santos TFM. Comportamentos de saúde oral e hábitos nutricionais associados à atividade física - estudo piloto. Dissertação apresentada à Universidade Católica Portuguesa [mestrado]. Instituto de ciências da Saúde. Viseu, 2013, 145 p.

16. Silva AMG, De Bonis R. Odontologia desportiva: a influência da saúde bucal na performance dos atletas da vila olímpica de Manaus. BIUS 2018; 9(1). 